\title{
INFLUENCE OF ALBASIA WOOD ON MECHANICAL PROPERTIES AND MORPHOLOGY OF EPOXY COMPOSITES
}

\author{
Henny Pratiwi
}

\author{
Aeronautics Department \\ Adisutjipto College of Technology \\ J1. Janti Blok R Lanud Adisutjipto \\ henny_pratiwi@stta.ac.id
}

\begin{abstract}
The development of composite products made from natural resources is increasing worldwide because of its availability and environmental issues. This research aims to investigate the effects of albasia wood filler as alternative reinforcement for extravagant and non-renewable filler being used in epoxy composites. The filler size used was 30 mesh and various filler volume fractions were 10, 20, 30 and 40 percent. Composites were manufactured using hand lay-up method. Properties such as tensile strength, elongation, modulus elasticity and strain energy absorption were determined based on ASTM standard. The results show that filler volume content significantly affects the tensile properties and impact strength of albasia wood-epoxy composites. The optimum tensile properties are achieved when 10 percent filler is added into epoxy matrix. The impact test also shows the same results. Further addition of filler decreases the mechanical properties of composites due to the existence of weak interfacial interaction between the albasia wood filler and polymer matrix for higher filler volume concentration beyond 10 vol. \%. The scanning electron micrograph reveals that there are voids and pull-out mechanism on tensile fracture surface which are the cause of the composites failure.
\end{abstract}

Keywords: composite, bio-filler, albasia wood, epoxy, mechanical properties.

\section{Abstrak}

Perkembangan produk komposit terbuat dari bahan alam meningkat disebabkan ketersediaan dan isu lingkungan. Penelitian ini bertujuan untuk mengetahui pengaruh serbuk kayu albasia sebagai alternatif penguat untuk serat mahal dan tidak dapat diperbaharui yang banyak digunakan pada komposit. Ukuran serat yang digunakan adalah 30 mesh dan variasi fraksi volume adalah 10, 20, 30 dan 40 persen. Komposit dimanufaktur menggunakan metode hand lay-up. Sifat komposit seperti kekuatan tarik, elongasi, modulus tarik dan energi serap diperoleh sesuai standar ASTM. Hasil penelitian menunjukkan bahwa fraksi volume berpengaruh signifikan terhadap sifat tarik dan kekuatan impak komposit serbuk kayu albasia-epoksi. Sifat tarik optimum dicapai ketika 10 persen serbuk ditambahkan pada matriks epoksi. Pengujian impak menunjukkan hasil yang sama. Penambahan serbuk lebih jauh akan menurunkan sifat mekanik komposit dikarenakan hubungan antarmuka serbuk kayu albasia dan matriks epoksi yang kurang baik untuk penambahan serbuk lebih besar dari 10 persen. Hasil foto scanning electron microscopy menunjukkan adanya void dan mekanisme pull-out pada permukaan patahan uji tarik komposit yang menjadi penyebab kegagalan komposit.

Kata kunci: komposit, serat alam, kayu albasia, epoksi, sifat mekanik. 


\section{Introduction}

Fiber reinforced plastic (FRP) composite materials are expected to increase continuously due to their strength to weight ratio, availability, and wide range of mechanical properties compared to metallic materials. Because of these outstanding attributes, composite materials have acquired important applications in automotive, marine and even aerospace industries. Delamination, associated with cracks propagation in composites, has become a challenge in composites manufacturing. There are some investigations on technique to delay delamination, which include fiber treatment [1], manufacturing process optimization [2], the using of different reinforcement [3] and filler content [4-6]. The research about filler content optimization stated that mechanical and surface properties are improved due to optimum filler content. However, higher filler concentration causes agglomeration, filler dispersion difficulties and higher composites velocity [7-8].

Bio-fillers accommodate ecofriendly alternatives of synthetic reinforcements which are non-renewable and, in some cases, considered as waste. These fillers are used to improve the properties of composites include mechanical and morphology properties. Some researchers have observed the effect of bio-filler addition on the properties of materials. Huang et al. [9] has investigated the effect of mechanical activation pretreatment on the properties of sugarcane bagasse/poly(vinyl chloride) composites and stated that inclusion of bio-fillers improved the tensile strength, tensile modulus, impact energy, hardness and thermal properties. This result is almost the same with other research that did an investigation about the effect of Mt. Kelud ash particle on polyester and epoxy composites where the addition of particles has improved the tensile and impact properties of composites [10]. Remarkable increase in toughness, tensile strength and thermal degradation temperature were obtained by other bio-fillers such as rice husk and date palm wood on hybrid glass epoxy composites $[11,12]$. The present study reveals the optimum filler content on mechanical properties and morphology of albasia wood-epoxy composites.

\section{Methods}

Albasia wood flour which sieved into 30 mesh with volume fraction of 10, 20, 30 and 40 percent was mixed with general purpose resin-epoxy (Bisphenol A- epichlorohydrin) Bakelite EPR 174 and hardener versamid 140 for 15 minutes. After the mixture was blended evenly, it was poured into the mold and allowed to cure or 15 days at room temperature inside the mold. In order to obtain a complete polymerization, the composites were kept in open air for 10 days. There are 5 samples prepared for each test. An ultimate tensile machine (Torsee AMU-5-DE) with specified loading rate of $10 \mathrm{~mm} / \mathrm{min}$ was utilized to evaluate the tensile specimens according to ASTM D638-91 standard. The Charpy impact (Hung Ta Instrument with $23.870 \mathrm{Kg}$ pendulum mass) test was conducted to investigate the impact resistance and energy absorbed of the composites according to the ASTM D790-02 standard. The tensile fracture surface then was examined by scanning electron microscope using JEOL 7800F SEM machine to observe the effects of filler on filler-matrix interfacial adhesion.

\section{Results and Discussions}

Deformation was measured for all specimens where $2000 \mathrm{~N}$ at loading rate of 10 $\mathrm{mm} / \mathrm{min}$ was applied. The deformation is larger for ductile materials than the brittle or stiffer materials because of same loading applied for all specimens. Elastic property of matrix, 
degree of filler impregnation by matrix, matrix filler interaction and filler volume content in composites are the factors contributed to material stiffness. Matrix/filler interaction was affected by filler ability to impregnate in matrix, nature of filler surface and filler aspect ratio. The 10 percent filler is highly impregnable by epoxy causes the albasia wood thoroughly mixed with epoxy and leaving no suspended particles. As a result, the homogeneous mix between matrix and filler was formed and the optimum tensile strength, tensile modulus and elongation were obtained (Figure 1). Composites that contained more than 10 percent filler are difficult to be impregnated by epoxy due to increasing of composites viscosity causing suspended particles agglomerated in matrix system. Form the figure we could also see that the deformability varies with filler volume percentage because filler addition tends to change the ductility of matrix. In this case, the lower the filler content, the higher the ductility. This is due to higher distance between particles causing polymer chain be allowed to move resulted in high ductility. Higher filler concentration decreases mean distance between particles so that the polymer mobility was constrained causing lower ductility and higher stiffness. This result is the same with the investigations done by [3] and [13]. They stated that higher filler volume content decreases mechanical properties of composites.

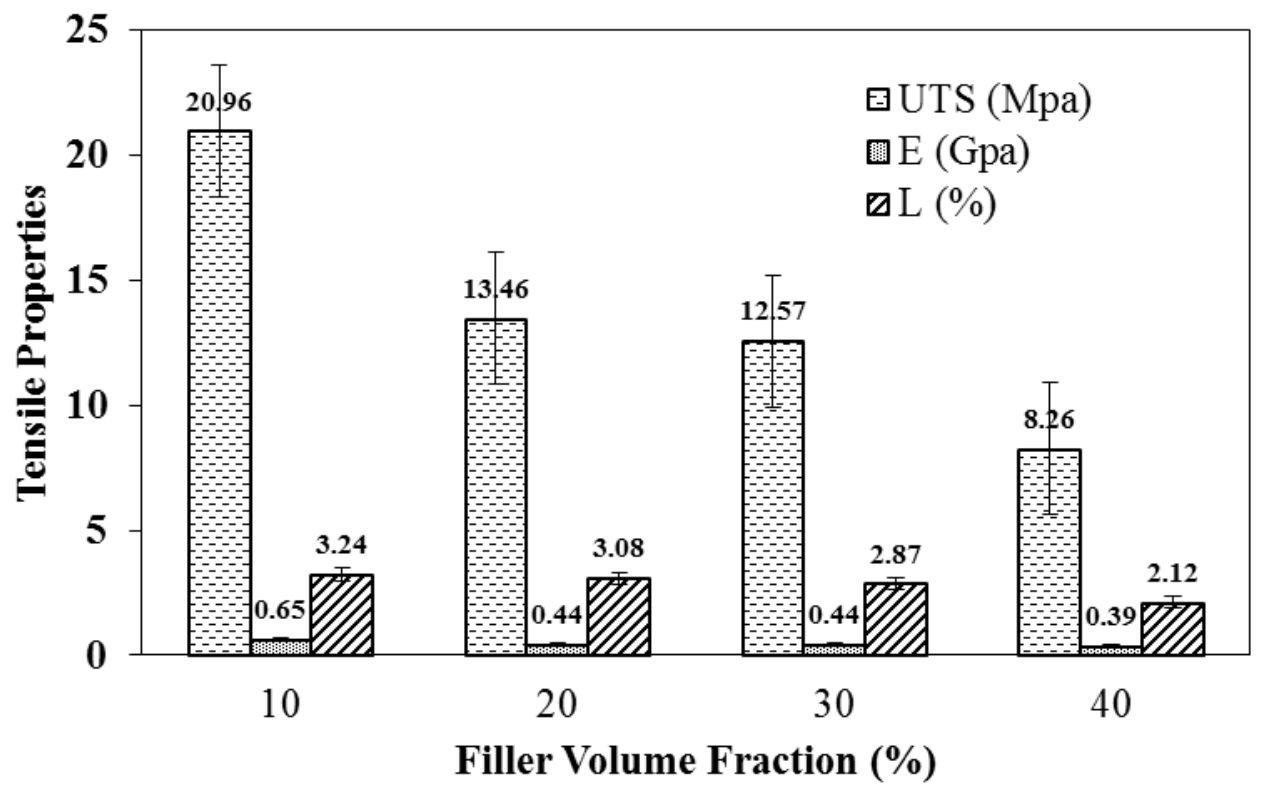

Figure 1 The effects of filler volume fraction on tensile properties of albasia wood - epoxy composites

The composites ability to resist fracture under load applied at high speed could be said as impact strength. The effects of filler content on impact strength of albasia wood-epoxy composites could be seen in Fig. 2. It could be concluded that the higher the filler volume fraction, the lower the impact strength where 10 percent filler volume fraction obtained the highest value. However, further addition of filler decreases the impact strength of composites. This may be because of the existence of weak interfacial interaction between the albasia wood filler and polymer matrix for higher filler concentration beyond $10 \mathrm{vol} . \%$. This result is supported by other investigations $[14,15]$ which reported that the addition of fillers up to some extent reduces the crack initiation energy thus degrades the impact strength of composites. 


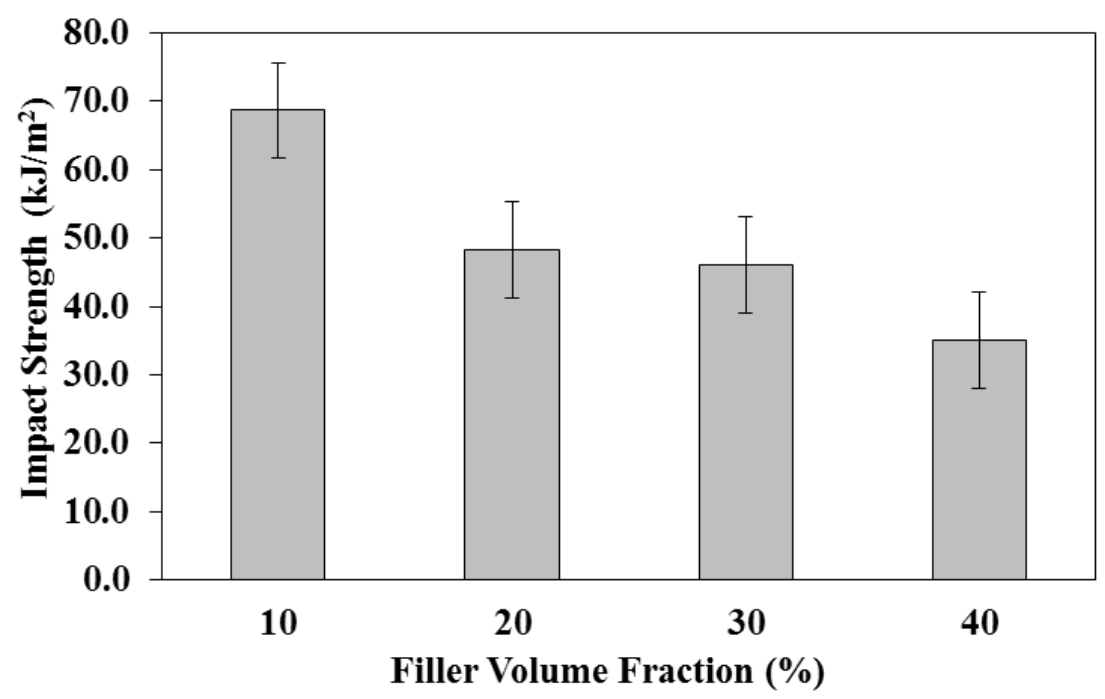

Figure 2 The effects of filler volume fraction on impact strength of albasia wood - epoxy composites

On the other side, the existence of voids and pull-out has highly contributed to the failure of composites (Fig. 3). Based on scanning electron micrograph of tensile fracture surface, it could be seen that there are some voids and pull-out mechanism. Pull-out mechanism is caused by poor interfacial connection between lignocellulosic filler and polymer matrix while voids are caused by air entrapped during composites manufacturing. These two factors lead to inefficient stress transfer between matrix and filler [16].
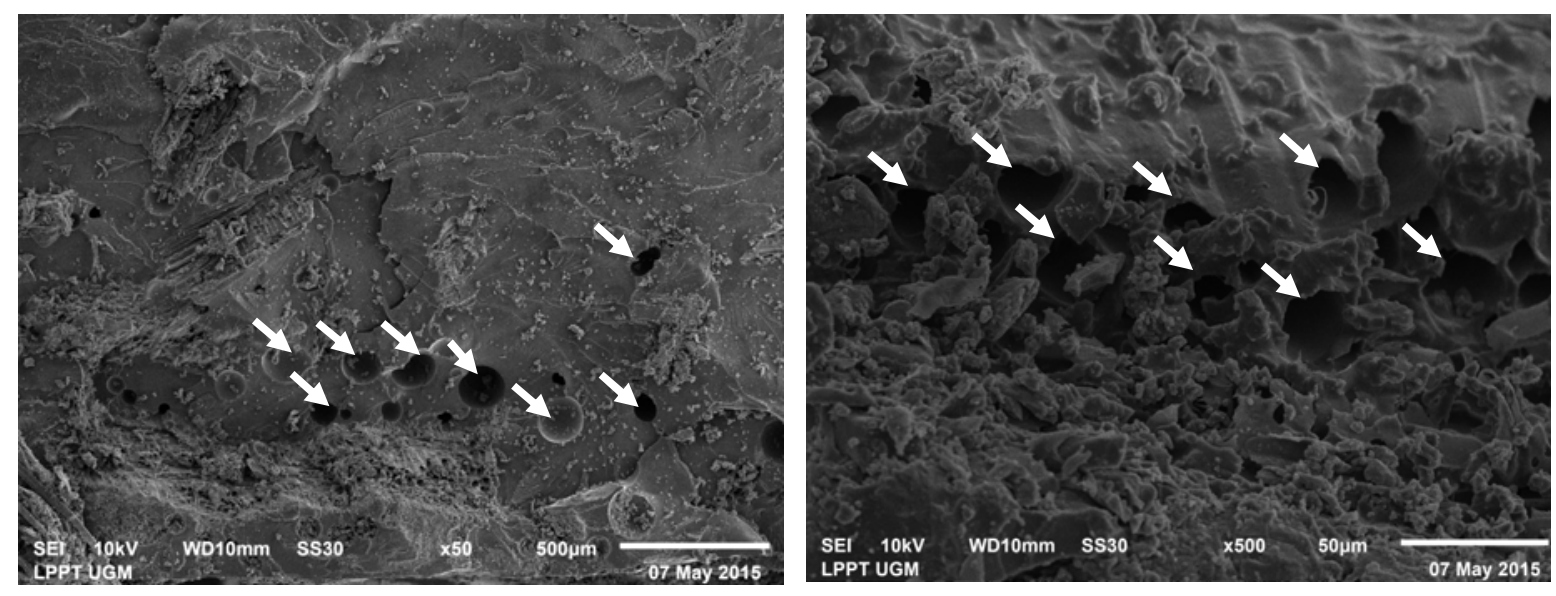

Figure 3 The SEM Micrograph of tensile fracture surface of albasia wood - epoxy composites for 10 percent filler volume content.

\section{Conclusions}

The effect of albasia wood filler volume fraction on mechanical properties and morphology of epoxy composites has been investigated and the results have been presented. Tensile and impact test results show that 10 percent is the optimum filler volume content in order to obtained the optimum tensile and impact properties. Higher filler content could degrade those properties due to suspended particles left caused by matrix difficulties to impregnate the high filler content. Tensile fracture surface observation reveals that voids and pull out are responsible for the failure of composites. 
References

[1] Sosiati, H, Pratiwi, H, Wijayanti, DA, 2015, The Influence of Alkali Treatments on Tensile Strength and Surface Morphology of Cellulose Microfibrils, Advanced Materials Research, Vol. 1123, pp. $147-150$.

[2] Pratiwi, H, 2016, The Effects of Mixing and Curing on Morphological and Mechanical Properties of Epoxy-Albasia Composites, Conference SENATIK STT Adisutjipto Yogyakarta, Vol. 2, pp. $55-61$.

[3] Sajith, S, Arumugam, V, Dhakal, HN, 2017, Comparison on Mechanical Properties of Lignocellulosic Flour Epoxy Composites Prepared by Using Coconut Shell, Rice Husk and Teakwood as Fillers, Polymer Testing, Vol. 58, pp. 60-69.

[4] Safaee, S, Yasrebi, B, 2017, Effect of an Increase in Nano-Filler Content on the Mechanical Properties of High-Leucite Composite Resins Useable in Dentistry, Crescent Journal of Medical and Biological Sciences, Vol. 4, No. 3, pp. $144-149$.

[5] Amaro, AM, Bernardo, L, Pinto, DG, Lopes, S, Rodrigues, J, Louro, CS, 2016, Effect of Irregular Shaped Nanoalumina on the Enhancement of Mechanical Properties of Epoxy Resin Nanocomposites Using DDM as Hardener, Composites Part B, Vol. 84, pp. $17-24$.

[6] Pinto, D, Bernardo, L, Amaro, A, Lopes, S, 2015, Mechanical Properties of Epoxy Nanocomposites Using Titanium Dioxide as Reinforcement - A review, Construction and Building Materials, Vol. 95, pp. $506-524$.

[7] Herrera-Ramírez, LC, Castell, P, Fernández-Blázquez, JP, Fernández, A, de Villoria, RG, 2015, How Do Graphite Nanoplates Affect the Fracture Toughness of Polypropylene Composites, Composite Science and Technology, Vol. 111, pp. $9-16$.

[8] Alzarrug, FA, Dimitrijević, MM, Heinemann, RMJ, Radojević, V, Stojanović DB, Uskoković, PS, Aleksić, R, 2015, The Use of Different Alumina Fillers for Improvement of the Mechanical Properties of Hybrid PMMA Composites, Materials and Design, Vol. 86, pp. $575-581$.

[9] Huang, Z, Wang, N, Zhang, Y, Hu, H, Luo, Y, 2012, Effect of Mechanical Activation Pretreatment on the Properties of Sugarcane Bagasse/Poly(Vinyl Chloride) Composites, Composites: Part A, Vol. 43, pp. $114-120$.

[10] Pratiwi, H, 2017, Morphological and Mechanical Properties of Mt. Kelud Volcanic Ash Reinforced Polyester and Epoxy Composites, Jurnal Teknik Mesin Universitas Mercu Buana, Vol. 6, pp. $47-52$.

[11] Rout, AK, Satapathy, A, 2012, Study on mechanical and tribo-performance of rice-husk filled glass-epoxy hybrid composites, Materials and Design, Vol. 41, pp. $131-141$.

[12] AlMaadeed, MA, Nogellova, Z, Micusik, M, Novak, I, Krupa, I, 2014, Mechanical, Absorption and Adhesive Properties of Composites Based on Low Density Polyethylene Filled with Date Palm Wood Powder, Materials and Design, Vol. 53, pp. 29-37.

[13] Manikandan, V, Richard, S, Thanu, MC, Rajadurai, JS, 2015, Effect of Fly Ash as Filler on Mechanical \& Frictional Properties of Jute Fiber Reinforced Composite, International Research Journal of Engineering and Technology, Vol. 02, Issue 07, pp. $154-158$.

[14] Bengtsson, M, Baillif, L, Oksman, K, 2007, Extrusion and Mechanical Properties of Highly Filled Cellulose Fibre-Polypropylene Composites, Composites Part A, Vol. 38, Issue 8, pp. $1922-1931$.

[15] Bharathkumar, B, Sasikumar, K, Bharathiraja G, Jayakumar, V, 2018, Study of Mechanical Properties of Algae Filler Vinylester Composite, International Journal of Pure and Applied Mathematics, Vol. 119, No. 12, pp. 15667 - 15676. 
[16] Obasi, HC, Iheaturu, NC, Onuoha, FN, Chike-Onyegbula, CO, Akanbi, MN, Ezeh, VO, 2014, Influence of Alkali Treatment and Fibre Content on the Properties of Oil Palm Press Fibre Reinforced Epoxy Biocomposites, American Journal of Engineering Research, Vol. 3, Issue 2, pp. $117-123$. 